IZA DP No. 9727

Integration of Ethnic Minorities:

Do They Divorce as Natives Do?

Marie Louise Schultz-Nielsen

Jens Bonke

February 2016

Forschungsinstitut

zur Zukunft der Arbeit

Institute for the Study

of Labor 


\title{
Integration of Ethnic Minorities: Do They Divorce as Natives Do?
}

\author{
Marie Louise Schultz-Nielsen \\ Rockwool Foundation Research Unit \\ and IZA \\ Jens Bonke \\ Rockwool Foundation Research Unit
}
Discussion Paper No. 9727
February 2016

\author{
IZA \\ P.O. Box 7240 \\ 53072 Bonn \\ Germany \\ Phone: +49-228-3894-0 \\ Fax: +49-228-3894-180 \\ E-mail: iza@iza.org
}

\begin{abstract}
Any opinions expressed here are those of the author(s) and not those of IZA. Research published in this series may include views on policy, but the institute itself takes no institutional policy positions. The IZA research network is committed to the IZA Guiding Principles of Research Integrity.

The Institute for the Study of Labor (IZA) in Bonn is a local and virtual international research center and a place of communication between science, politics and business. IZA is an independent nonprofit organization supported by Deutsche Post Foundation. The center is associated with the University of Bonn and offers a stimulating research environment through its international network, workshops and conferences, data service, project support, research visits and doctoral program. IZA engages in (i) original and internationally competitive research in all fields of labor economics, (ii) development of policy concepts, and (iii) dissemination of research results and concepts to the interested public.
\end{abstract}

IZA Discussion Papers often represent preliminary work and are circulated to encourage discussion. Citation of such a paper should account for its provisional character. A revised version may be available directly from the author. 
IZA Discussion Paper No. 9727

February 2016

\section{ABSTRACT}

\section{Integration of Ethnic Minorities: Do They Divorce as Natives Do?*}

We investigate the divorce patterns among non-Western immigrants and natives in Denmark. We focus on marriages entered on or after arrival to Denmark and analyze whether inter-ethnic marriages result in higher divorce rates and whether divorce behavior differs between first- and second-generation immigrants and native couples. We show that inter-ethnic couples (one native, one immigrant) in general are more likely to divorce than native couples (two natives), while co-ethnic couples (two immigrants) are less likely to divorce, when controlling for differences in socioeconomic characteristics. In particular, co-ethnic couples composed of a first- and second-generation immigrant are less likely to divorce, while the divorce probability is the highest among inter-ethnic couples composed of a native woman and a first-generation immigrant man. The analyses are based on register information from Statistics Denmark for the years 1990-2014.

JEL Classification: J12, J15, D13

Keywords: inter- and co-ethnic marriage and divorce

Corresponding author:

Marie Louise Schultz-Nielsen

The Rockwool Foundation Research Unit

Sølvgade 10

1307 Copenhagen K

Denmark

E-mail: mls@rff.dk

\footnotetext{
* We thank Emilie Damm and Mikkel Mertz for computational assistance. We also thank Professor Mette Verner and the seminar participants at the Rockwool Foundation Research Unit. The authors are solely responsible for any views expressed.
} 


\section{Introduction}

The aim of this study is to analyze whether some types of ethnic couple divorce more frequently than others and whether their divorce patterns differ from those of natives. In the existing literature inter-ethnic marriages are often associated with higher divorce rates. We go further and analyze whether it matters if it is the husband or the wife who is the immigrant in these inter-ethnic marriages. We also investigate the differences in divorce patterns for combinations of first- and second-generation immigrants.

More specifically, we analyze the divorce pattern among nine ethnic combinations of husband and wife (match types) that include natives, and first- and second-generation immigrants. We include non-Western immigrants and natives; couples including Western immigrants are excluded. This is to minimize the number of match types ( 9 instead of 25 ) while retaining a sufficiently large sample of second-generation immigrants to investigate the possible differences in divorce patterns between first- and second-generation immigrants; further, the number of second generation immigrants from non-Western countries is much larger than from Western countries. We concentrate on couples living in Denmark at the time of marriage or within 12 months of the marriage, giving us the advantage of following the couple over the years.

The data stem from administrative register information in Statistics Denmark and include information on both spouses' age at marriage, educational length, income and unemployment experience in Denmark. The analyses are based on probit estimations.

The paper is organized as follows: Section 2 summarizes the previous literature, Section 3 describes the data, Section 4 contains descriptive statistics, Section 5 explains the empirical strategy and Section 6 the main results; Section 7 concludes.

\section{Previous literature}

In the past decades there has been a rise in divorce rates in most Western countries (White, 1990). This has resulted in a comprehensive literature concerning the determinants of divorce. One often-mentioned determinant of the rising divorce rate is women's growing labor market participation and according increased independence from their husband's income; another factor is the changed divorce laws (Peters, 1986; Allen, 1992; Peters, 1992; Friedberg, 1998; Wolfers, 2006). These papers analyze variations in divorce laws across US states and emphasize the important effects of divorce laws on intra-household bargaining; nevertheless, a large part of the change in divorce rates remains unexplained. Other studies point to the central role of changing social norms (Frimmel et al., 2013).

A general framework for analyzing marriage behavior within economic theory is provided by Becker $(1973,1974,1993)$. Marriage is seen as a voluntary partnership where spouses share their joint production and consumption. The matching of spouses happens on the marriage market and the match depends on the characteristics of each spouse. 
According to Browning, Chiappori and Weiss (2014) the probability to marry and to divorce can be explained within a model where couples tend to marry (and stay married) if each partner's utility of being married exceeds the utility of being single. Hence, both partners select a marriage based on their own and their partner's characteristics. For each spouse, the utility of the marriage depends on both the economic gain from marriage and the nonpecuniary benefits, for example, love and companionship. These gains are match specific and may differ between the partners and are assumed to be revealed with some lag, i.e. during the marriage.

For simplicity, the model has only two periods. In the first period agents marry and benefit from joint consumption; in the second period the match quality is revealed and couples decide to stay married or divorce. If they stay married, they continue to benefit from joint production and consumption during the second period and obtain nonpecuniary benefits. Hence, marriage will continue in the second period if marriage is preferred over divorce by both spouses, which implies that divorce will occur if at least one spouse is better off as a single.

To be better off after divorce is not only related to pecuniary assets, satisfaction with everyday life can also be improved by divorce. That is, engagement in household tasks and upbringing of children requires some agreements between spouses that are more difficult to obtain in the case of differing norms and social values. Hence the importance of the couple's homogeneity has also been discussed, such as differences in age (Yi and Chien, 2006), in education (Tzeng, 1992) and in religion (Curtis and Ellison, 2002; Kalmijn, de Graaf, and Janssen, 2005; Bratter and King, 2008).

Ethnicity has also been studied as a factor distinguishing between heterogamous and homogamous marriages. However, for Britain, Feng et al. (2012) find no evidence of a higher risk of dissolution between mixed-ethnic unions and co-ethnic immigrant or British unions controlling for the younger age of persons in mixed-ethnic unions (Feng et $a l ., 2012$ ). This contradicts the general finding that the divorce risk for heterogamous marriages is higher than for homogamous marriages due to cultural differences and an increased risk of disapproval and lack of social support, see literature review in Eeckhaut et al. (2011). The reconciliation of two cultures is more difficult when values, interests and expectations regarding role performances can enforce more marital conflicts and, ultimately, divorce (Jorgensen and Klein, 1979), albeit an alternative argument has been proposed inasmuch as a mixed-ethnic partnership illustrates increasing mutual acceptance of ethnic groups (Bratter and King, 2008). Apart from the initial choice of the partner, not only the spouses themselves, but also their families can affect the stability of the marriage. In communities with a collectivistic value orientation, the influence of the family can be especially strong. Hence parents representing such values may suppport homogamy and representation of own behavior for the benefit of the internal cohesion of the group or to defend their interests. The implication is that third party preferences, and not only individual preferences and norms, display a heightened instability and risk of divorce in heterogamous marriages and a smaller likelihood of being formed.

Some homogamous marriages are believed to be systematically subject to cultural differences. A marriage between a person from an ethnic minority group and a partner from the same country of origin who migrated through marriage, so-called family migration (Portes and 
Böröcz, 1989), is an example of a possibly unstable marriage, with the subsequent increased risk of divorce. This arises from differences between the spouses in terms of norms and expectations regarding gender roles. Both marital partners have grown up in different countries and have experienced different ways of living, and the partner from the country of origin-the first-generation immigrant-might be confronted with adjustment problems in his/her new country. Nonetheless, immigrants do not necessarily fully represent their population of origin (Chiswick, 1978; Andersson et al., 2015).

In contrast, marrying a partner from the country of origin, especially a second-generation immigrant, and thereby forming a homogamous marriage is perceived as a lack of integration (Eeckhaut et al., 2011). This might diminish the likelihood of divorce for which reason the impact of such marriages on divorce is an empirical question, although it is argued that the instability of these marriages is less than that of ethnic heterogamous marriages (ibid, p. 277).

Nevertheless, homogamous marriages where immigrants marry other immigrants are common in Western countries (Meng and Gregory, 2005), as is the case in Denmark where non-Western immigrants often find futures spouse from the country of origin (Schultz-Nielsen, 2010).

Structural factors are important for the formation and maintenance of intimate unions (Becker, 1991; Ruggles, 1997). For men, in particular, financial independence and stability are prerequisites for marriage, making them more "marriageable", for which reason less stable earnings during periods with economic crises decrease the quality of marriages and increase the number of divorces. In most countries, more immigrant than native men are at the margin on the labor market and thereby at risk of losing their jobs-Black and Mexican American couples are much more likely to be poor and less likely to be married than are White couples in the US (Casper and Bianchi, 2002; United States Census Bureau, 2011). In addition, fewer non-

Western immigrant men than native Danish men have completed an education, and the same holds for non-Western immigrant women relatively to native Danish women. Accordingly, inter-ethnic marriages may be seen as less attractive from a native perspective than do co-ethnic marriages and carry a subsequently higher risk of divorce.

Lastly, couples with children are considered less likely to break up because of a higher match quality and more investments in the future, i.e. in children. Hence, divorces might be more costly when there are children in the family. However, Björklund and Sundström (2006) and Svarer and Verner (2008) argue that much of the difference in child attainment precedes the divorce, and that lower divorce rates among families with children compared with those without children can be explained by higher match qualities rather than by the presence of children. 


\section{Data}

We use register data for all persons with residence in Denmark from Statistics Denmark for the period 1990 to 2014. The Population Register includes all persons living in Denmark on January 1 each year and includes information about sex, age, marital status, date of marriage/divorce, partner's social security number, immigrant status and country of origin. The Income Statistics Register contains information from the tax authorities for all taxpayers on annual income, including cross income. Information about educational skills can be found in the Educational Register. The education and length of education are measured for all persons who have undergone education in Denmark since 1980; information about older persons comes from a population census. Immigrants who do not have a Danish education are asked about their educational achievements by Statistics Denmark. Lastly, we include information about annual unemployment rate from the Central Register for Labor Market Statistics (CRAM).

On the basis of the population register we found all couples married within a given year during 1990-2009. ${ }^{1}$ As we condition on characteristics of both spouses in the analysis, both spouses should be present in Denmark the year after marriage for the couple to be included in the sample. Including couples already married on arrival, would have systematically underestimated the divorce rates of immigrant couples (Statistics Denmark, 2010). Accordingly, we investigated divorce behavior among couples where marriage formation took place on or after arrival to Denmark.

Based on information about country of origin and, for immigrants, age on arrival in Denmark, we distinguish between three types of spouses: persons of native Danish origin, firstgeneration non-Western immigrants, and second-generation non-Western immigrants. We restrict the sample to first marriages. Marriages involving Western ${ }^{2}$ immigrants are excluded in the analysis in order to minimize the number of match types ( 9 instead of 25) and to avoid including match types with few observations, such as second-generation Western immigrants.

Persons of native Danish origin (or simply natives) are classified here as: persons with at least one parent who is a Danish citizen born in Denmark (Statistics Denmark, 2013a). All others are considered immigrants. If immigrants were born in Denmark or were younger than 15 years on arrival in Denmark, we classify them as second-generation immigrants; all others are classified as first-generation immigrants.

Based on the three ethnic types of spouse, we identify nine match types depending on the ethnic origin of both husband and wife. In the vast majority, spouses are of native Danish origin and are referred to as native couples. Among these native couples we draw a 10 percent random sample, whereas for the other types of couple we include all observations from the

\footnotetext{
${ }^{1}$ Cohabiting couples are not included in the analysis. The reason is that the accuracy of the information regarding cohabitants is less precise than that regarding married couples. However, many cohabiting couples eventually marry and are then included in the analysis.

${ }^{2}$ Western countries include: the 28 countries of the European Union (except Croatia) plus Andorra, Iceland, Lichtenstein, Monaco, Norway, San Marino, Switzerland, the Vatican State, Canada, the USA, Australia and New Zealand.
} 
administrative registers. Although the number of first-generation immigrants has risen markedly from 1980, there are few of the child generation (2. Generation) who have reached marriage age.

All types of couple that include a native and an immigrant (first or second generation) are referred to as inter-ethnic couples, while couples that include two immigrants (first or second generation) are called co-ethnic couples. In principle, spouses in co-ethnic couples can origin from all non-Western countries, but in 80 percent of the cases the two spouses share country of origin.

Figure 1. Proportion of married couples that stay married, depending on years since marriage. Native Danes and non-Western immigrants included.

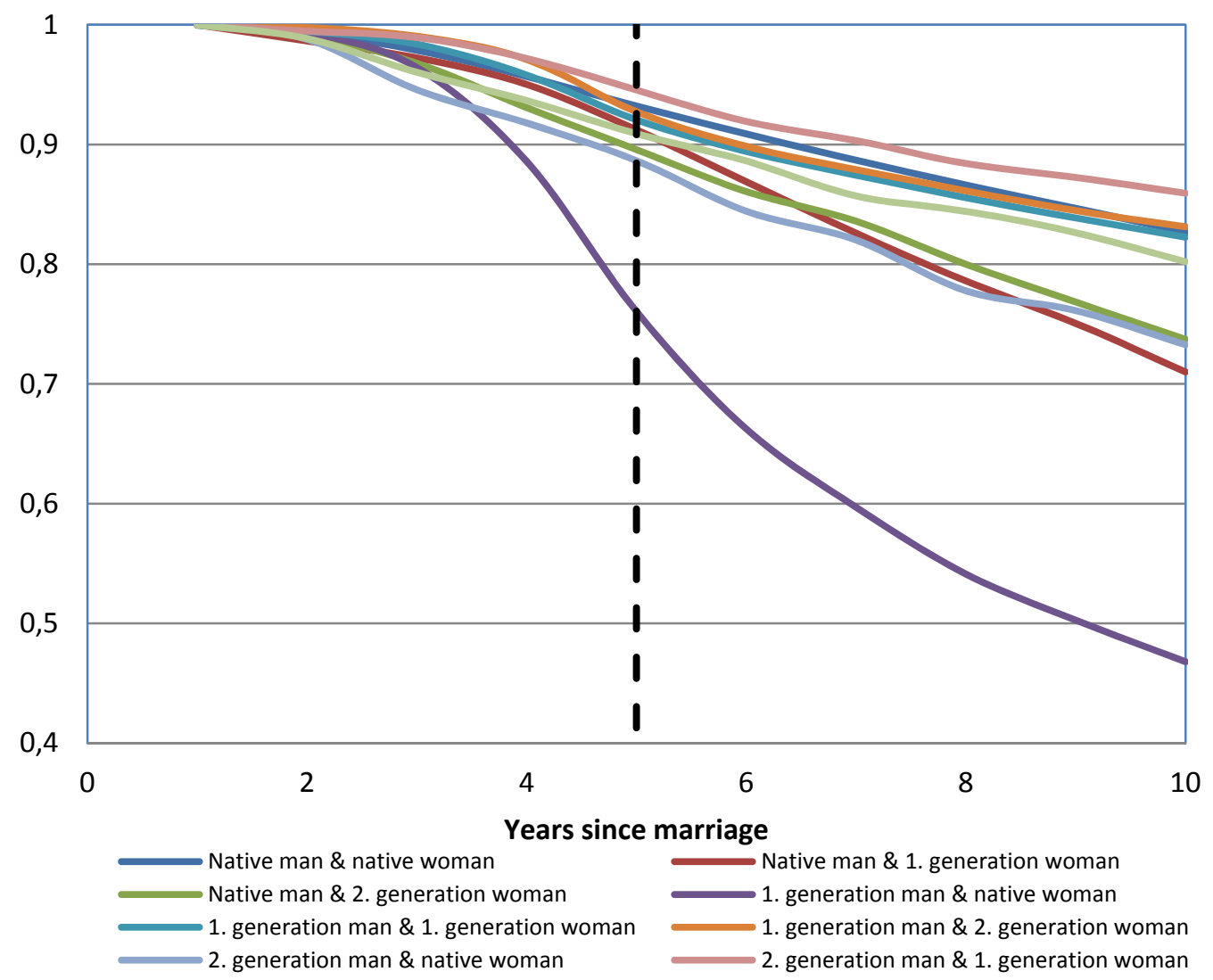

Source: Own calculations based on Statistics Denmark's registers.

We include information about each spouse's demographic and socioeconomic characteristics around the time they were married. In practice, this information is collected the year after they are married as newly immigrated spouses are then also covered. Other variables include a measure for each spouse's unemployment rate the year before divorce/after five years of marriage and whether the couple is divorced five years after their marriage, see the divorce patterns in Figure 1. 
We end up with a sample that consists of 71,535 couples married in the period 1990-2009. The sample is split into two: 41,024 couples where both spouses are natives, i.e. 10 percent of the entire group, and 30,511 couples of ethnic or inter-ethnic origin. Owing to the reduced sample for natives, we use a weight factor 10 in the regression analysis for these observations.

\section{Descriptive statistics}

To investigate differences in divorce rates over match types, we introduce a set of explanatory variables in Table 1 along with the main variable of interest: divorce rate. We see from the table that the divorce rate after 5 years of marriage is on average 11 percent for the ethnic and inter-ethnic couples, whereas it is considerably lower at 7 percent for the native couples.

On average the women are 30.5 years old when married in native couples against 27.5 years old in ethnic or inter-ethnic couples. The husband tends to be older than the wife. In 20 percent of the native couples the husband is more than four years older than the wife as opposed to 37 percent among ethnic and inter-ethnic couples. In 30 percent of the native couples the husband is $2-4$ years older than his wife; this is the case in only 24 percent of the ethnic and inter-ethnic couples. Consequently, the husband is less than 2 years older (and in some cases younger) than his wife among 50 percent of native couples, while this is the case for 39 percent of ethnic and inter-ethnic couples. Overall, the age gap between spouses is larger in ethnic and inter-ethnic couples than among native couples.

Information about educational attainment is available for all native couples but is unknown for 24 percent of the women and 19 percent of the men in ethnic and mixed couples. This is expected as education obtained out of Denmark is not fully covered in the Danish registers and is collected by survey. For those ethnic and inter-ethnic couples where the education is known, the average length of education is 140.6 months or 11.7 years for women and somewhat longer (7.1 months) for men. Among native couples the average length of education is 155.6 months or 13 years for women and only slightly longer (1.4 months) for men. Larger differences between native spouses are found regarding income. The women's gross income in 2012-prises was 266,400 DKK or approximately 45.953 USD $^{3}$, while the men's gross income was 115,100 DKK higher. For couples of ethnic and inter-ethnic origin the man's income for the same year was an average of 101,800 DKK higher than the woman's, but the average income level was much lower: 114,200 DKK in 2012-prices. In contrast, the unemployment rates were higher: on average 12 percent for husbands and 9 percent for wives in ethnic or inter-ethnic couples against 3 and 5 percent for husband and wives, respectively, in native couples.

Among the 30,511 couples of ethnic and inter-ethnic origin, in Table 1 we find that 28 percent are native men married to first-generation women, whereas only few of the native men are married to second-generation women-3 percent in our sample. In 17 percent of the couples the husband is a first-generation immigrant married to a native woman, whereas 29 percent are couples where both spouses are first-generation immigrants (typically from the same

\footnotetext{
${ }^{3}$ The average exchange rate in 2012 was 579.72 DKK for 100 USD (Statistics Denmark, 2013b).
} 
country of origin) and 8 percent are couples where the first-generation man is married to a second-generation woman.

Table 1 Descriptive Statistics, First marriages among co-ethnic and inter-ethnic, and native couples in Denmark, 1990-2009

\begin{tabular}{|c|c|c|c|c|}
\hline & \multicolumn{2}{|c|}{$\begin{array}{l}\text { Co-ethnic and inter- } \\
\text { ethnic couples }\end{array}$} & \multicolumn{2}{|c|}{ Native couples ${ }^{1}$} \\
\hline & Mean & $\begin{array}{l}\text { Standard } \\
\text { deviation }\end{array}$ & Mean & $\begin{array}{l}\text { Standard } \\
\text { deviation }\end{array}$ \\
\hline Divorced after 5 years, (0/1) & 0.11 & 0.31 & 0.07 & 0.25 \\
\hline \multicolumn{5}{|l|}{ Controls I } \\
\hline Women's age at marriage & 27.51 & 8.02 & 30.46 & 6.74 \\
\hline Man less than 2 years older than woman $(0 / 1)$ & 0.39 & 0.49 & 0.50 & 0.50 \\
\hline Man $2-4$ years older than woman $(0 / 1)$ & 0.24 & 0.43 & 0.30 & 0.46 \\
\hline Man more than 4 years older than woman $(0 / 1)$ & 0.37 & 0.48 & 0.20 & 0.40 \\
\hline \multicolumn{5}{|l|}{ Controls II } \\
\hline Women's educational length in months & 140.61 & 35.07 & 155.57 & 27.43 \\
\hline$\Delta$ Educational length (men-women), in months & 7.13 & 41.53 & 1.38 & 29.88 \\
\hline Women's education unknown (0/1) & 0.24 & 0.43 & 0.01 & 0.07 \\
\hline Men's education unknown (0/1) & 0.19 & 0.39 & 0.01 & 0.08 \\
\hline Women's gross income in DKK 10,000 & 11.42 & 12.58 & 26.64 & 11.76 \\
\hline$\Delta$ Gross income (men-women) in DKK 10,000 & 10.18 & 23.91 & 11.51 & 27.37 \\
\hline Women's unemployment rate & 0.09 & 0.21 & 0.05 & 0.15 \\
\hline Men's unemployment rate & 0.12 & 0.24 & 0.03 & 0.11 \\
\hline Types of couples: & Proportion & & Proportion & \\
\hline Native men \& native women & & & 1.00 & 0.00 \\
\hline Native men \& 1. gen. women & 0.28 & 0.45 & & \\
\hline Native men \& 2. gen. women & 0.03 & 0.18 & & \\
\hline 1. gen. men \& native women & 0.17 & 0.37 & & \\
\hline 1. gen. men \& 1. gen. women & 0.29 & 0.45 & & \\
\hline 1. gen. men \& 2. gen. women & 0.08 & 0.27 & & \\
\hline 2. gen. men \& native women & 0.03 & 0.16 & & \\
\hline 2. gen. men \& 1. gen. women & 0.06 & 0.23 & & \\
\hline 2. gen. men \& 2. gen. women & 0.07 & 0.26 & & \\
\hline No. of observations & 30,511 & & & 024 \\
\hline
\end{tabular}

${ }^{1} 10$ percent of native couples included.

Source: Own calculations

In only 3 percent of the couples is the husband a second-generation immigrant married to a native woman, which is mostly due to the small number of adult second-generation immi- 
grants. Couples with second-generation immigrant husbands and first-generation wives constitute 6 percent of the ethnic and inter-ethnic couples, while another 7 percent of secondgeneration immigrant husbands are married to second-generation wives.

In our analysis we focus on the probability of being divorced after five years of marriage to examine whether divorce behavior after such a relatively short period is representative of the general divorce behavior, see Figure 1 with marriage endurance rates of different match types. Couples are followed from the time of marriage and the first ten years after their marriage. In terms of this study, note that couples married after 2003 have not yet had the chance of being married 10 years and are therefore represented only in the first years.

More couples are divorced after eight than after five years, but as Figure 1 shows the divorce behavior is stable over the years across match types, meaning that those couples who have higher divorce rates after 4 or 5 years are the same as those after 8 years. The main exception is couples consisting of a second-generation husband and a native wife. They have a divorce rate that is relatively high after 5 years, but it seems to be only slightly higher after 8 and 9 years. However, it may be due to uncertainty as it is also one of the groups with the least observations after 8 years of marriage. For the other groups the divorce rate after 5 years seems to accurately reflect the overall marriage behavior within the first 10 years of marriage. Moreover, an analysis after 5 years of marriage, rather than after 10 or 20 years, has the advantage of being able to include later cohorts and thereby increasing both actuality and observation number.

\section{Empirical strategy}

Our aim is to analyze whether some types of couples of inter-ethnic and co-ethnic origin divorce more frequently than others. We know from the literature that inter-ethnic marriages often result in higher divorce rates. But does it matter whether it is the husband or wife who is an immigrant, and is the divorce behavior different for second-generation immigrants compared with first-generation immigrants?

To address these questions, we first use the following empirical strategy to estimate the divorce probability five years after the marriage depending on ethnic composition.

1) $Y_{i}=\alpha_{0}+\beta_{2}$ Matchtype $2_{i}+\ldots \ldots .+\beta_{9}$ Mathtype $_{i}+X_{i} \beta+\varepsilon_{i}$,

, where $\mathrm{Y}$ is the probability of a couple (i) being divorced five years after the marriage took place.

The following control variables $\left(X_{i}\right)$ are included in the estimations for both spouses: age at marriage, length of education, employment status and income-all measured at time of marriage. We also include both spouses' unemployment rate the year before divorce/after 4 years of marriage. 
Although at the time of marriage each spouse has some information about his or her partner's general view on labor division etc., this information may not apply when new situations and problems arise over the years. In these new situations the reference point for each spouse may be the habits and views in the country of origin. Accordingly, having the same country of origin may be an advantage.

All models are estimated as probit regressions.

\section{Results}

The result of estimating the probability of being divorced after 5 years of marriage is shown in Table 2 where marginal effects from probit estimations are reported. The corresponding probit models can be found in appendix Table 1 .

In the first column of Table 2 the only variables included in the model are the couples' matchtype, where inter-ethnic and co-ethnic couples are compared with couples of two native spouses. Focusing first on the inter-ethnic couples, the estimation confirms the result from Figure 1, namely that first-generation men married to native women are much more likely to be divorced than other couples. In fact their divorce probability is on average 10.5 percentage points higher than that of couples were both spouses are natives. Moreover, a relatively high divorce probability ( 3.8 percentage point) is found for second-generation men married to a native woman.

For couples with a native husband and a first- or second-generation immigrant wife, the divorce probability rates are also higher than those of native couples, but here "only" 1.8 and 3.3 percentage points. Hence, all inter-ethnic couples (including one native) have a higher divorce risk than that of native couples.

For some co-ethnic couples we find divorce rates similar to those of inter-ethnic couples, namely for second-generation men married to second-generation women (2.2 percentage points). For first-generation husbands married to first-generation wives the divorce risk is 1.1 percentage points higher than that of native couples. However, the opposite is the case for second-generation husbands married to first-generation wives, whose divorce risk is lower (1.9 percentage points) than that of native couples. Hence, the gender combination of being a first or second generation immigrant seems to matter.

Some of the differences in divorce patterns found in the first column in Table 1 can be explained by factors other than the ethnic composition of the couple. To test that, we include other explanatory variables and see how that changes the estimations of the match types. The underlying assumption when controlling for these characteristics is that they affect the divorce probability for immigrants and natives in the same manner. This also tends to be the case in Table 2, except age at marriage, were the pattern is very different for young women of native and immigrant origin. As people tend to marry someone close to their own age, some of the same pattern, but less pronounced, is found for young men of native and immigrant origin. 
The divorce probability by age at marriage is plotted in Figure 2 showing a large but declining divorce probability by age for natives. A test confirms the divorce probability is significantly higher for natives until the age of 23 years. Only 2 percent of the native women in the sample are younger than 22 years at marriage and an additional 9 percent younger than 24 years. However, among immigrants there has been a tradition of marrying earlier and the corresponding numbers are 20 and 18 percent among immigrant women.

Table 2. Probability of being divorced after 5 years of marriage by match types, Probit models, marginal effects

\begin{tabular}{|c|c|c|c|c|c|c|c|c|c|}
\hline & $\begin{array}{c}(1) \\
\text { Marginal } \\
\text { effect }\end{array}$ & & St. err. & $\begin{array}{c}(2) \\
\text { Marginal } \\
\text { effect }\end{array}$ & & St. err. & $\begin{array}{c}\text { (3) } \\
\text { Marginal } \\
\text { effect }\end{array}$ & & St. err. \\
\hline $\begin{array}{l}\text { Native men \& native women } \\
\text { Co-ethnic couples }\end{array}$ & - & & & - & & & - & & \\
\hline 1. gen. men \& 1. gen. women & 0.0117 & $* * *$ & $(0.003)$ & -0.0079 & $* *$ & $(0.003)$ & -0.0359 & $* * *$ & $(0.005)$ \\
\hline 1. gen. men \& 2. gen. women & 0.0023 & & $(0.005)$ & -0.0561 & $* * *$ & $(0.007)$ & -0.0851 & $* * *$ & $(0.008)$ \\
\hline 2. gen. men \& 1 . gen. women & -0.0186 & $* * *$ & $(0.007)$ & -0.0750 & $* * *$ & $(0.008)$ & -0.0942 & $* * *$ & (0.009) \\
\hline 2. gen. men \& 2. gen. women & 0.0224 & $* * *$ & $(0.005)$ & -0.0269 & $* * *$ & $(0.006)$ & -0.0349 & $* * *$ & $(0.006)$ \\
\hline Inter-ethnic couples & & & & & & & & & \\
\hline Native men $\& 1$. gen. women & 0.0181 & $* * *$ & $(0.003)$ & 0.0106 & $* * *$ & $(0.003)$ & 0.0037 & & $(0.004)$ \\
\hline Native men \& 2. gen. women & 0.0329 & $* * *$ & $(0.007)$ & 0.0171 & $* *$ & $(0.007)$ & 0.0166 & $* *$ & $(0.007)$ \\
\hline 1. gen. men \& native women & 0.1054 & $* * *$ & $(0.003)$ & 0.0958 & $* * *$ & $(0.003)$ & 0.0607 & $* * *$ & $(0.004)$ \\
\hline 2. gen. men \& native women & 0.0380 & $* * *$ & $(0.008)$ & 0.0236 & $* * *$ & $(0.008)$ & 0.0131 & $*$ & $(0.008)$ \\
\hline Women's age at marriage & & & & -0.0048 & $* * *$ & $(0.000)$ & -0.0028 & $* * *$ & $(0.000)$ \\
\hline $\begin{array}{l}\text { Man less than two years older } \\
\text { than woman }(0 / 1)\end{array}$ & & & & 0.0109 & $* * *$ & $(0.003)$ & 0.0072 & $* * *$ & $(0.003)$ \\
\hline $\begin{array}{l}\text { Man more than four years } \\
\text { older than woman }(0 / 1)\end{array}$ & & & & 0.0109 & $* * *$ & $(0.003)$ & 0.0082 & $* *$ & $(0.003)$ \\
\hline $\begin{array}{l}\text { Women's educational length, } \\
\text { years }\end{array}$ & & & & & & & -0.0129 & $* * *$ & (0.001) \\
\hline $\begin{array}{l}\Delta \text { educational length (men- } \\
\text { women), years }\end{array}$ & & & & & & & -0.0061 & $* * *$ & $(0.001)$ \\
\hline $\begin{array}{l}\text { Women's education missing } \\
(0 / 1)\end{array}$ & & & & & & & -0.0774 & $* * *$ & (0.009) \\
\hline $\begin{array}{l}\text { Men's education missing } \\
(0 / 1)\end{array}$ & & & & & & & -0.0622 & $* * *$ & $(0.009)$ \\
\hline $\begin{array}{l}\text { Women's gross income in } \\
\text { DKK } 10,000\end{array}$ & & & & & & & -0.0002 & & $(0.000)$ \\
\hline $\begin{array}{l}\Delta \text { income (men-women) in } \\
\text { DKK } 10,000\end{array}$ & & & & & & & -0.0004 & $* * *$ & $(0.000)$ \\
\hline Women's unemployment rate & & & & & & & 0.0506 & $* * *$ & $(0.006)$ \\
\hline Men's unemployment rate & & & & & & & 0.0765 & $* * *$ & $(0.007)$ \\
\hline Observations & 71535 & & & 71535 & & & 71227 & & \\
\hline Pseudo $\mathrm{R}^{2}$ & 0.007 & & & 0.022 & & & 0.054 & & \\
\hline
\end{tabular}

Delta method standard errors in parentheses

$* p<0.10 * * p<0.05 * * * p<0.01$

In the second column of Table 2 we control for women's age at marriage by a third grade polynomial and two dummies for age difference between spouses. Here we see that the average marginal effect of age is negative and thereby reaches the typical finding that women who are 
older (and more mature) at marriage lower the risk of divorce. We also control for age differences between the spouses and find that couples where men are 2-4 years older than their wives have a lower divorce risk. Hence, we still find that the probability of divorce after 5 years is significantly higher for inter-ethnic couples than for couples where both partners are natives. For co-ethnic couples the divorce rate for first-generation men married to firstgeneration women is now significantly less than that of native couples, the divorce rates for second-generation women married to first- or second-generation men have become lower than native couples' divorce rates, and the divorce rate for second-generation men married to first-generation women has now become much lower than for native couples, relatively to not controlling for age and spouses' age differentials. The reason is that natives are generally older when they marry and have less age dispersion between spouses than immigrants do, see Table 1. To check for the differences in divorce patterns for young immigrants and natives, we run a test where we exclude native couples where the women were younger than 23 years, see Appendix table 4 . This does not greatly change for the inter-ethnic couples, only the co-ethnic couples with first- and second-generation spouses have significantly lower estimates than native couples.

Figure 2. Divorce rates after 5 years of marriage, immigrant and native women

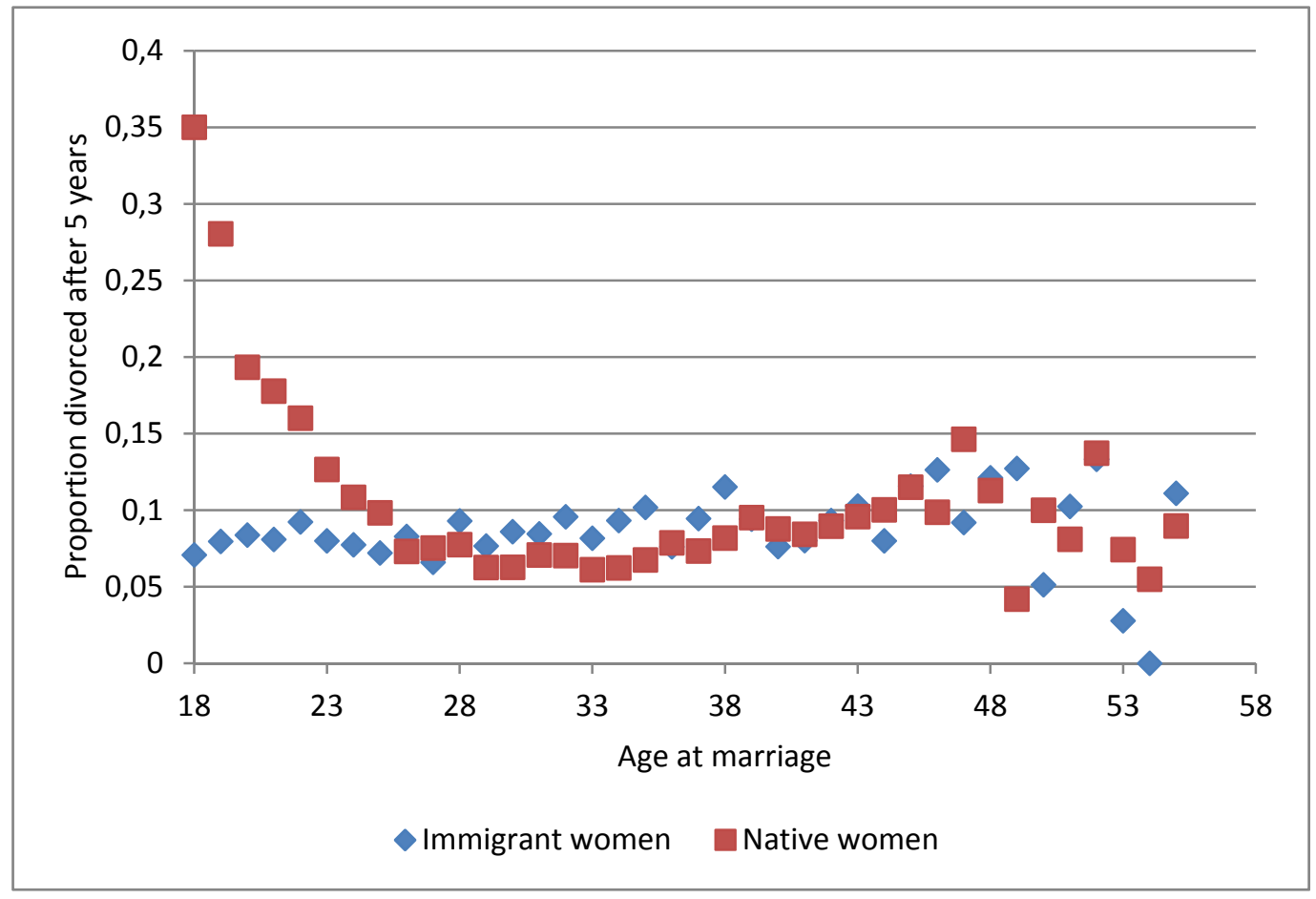

In column 3 we also include controls for educational background, the spouses' income and unemployment rates. The divorce probability lowers with women's educational length and also with men with a longer education. Women with no information on educational attainment have on average the same divorce probability as women with 6 years of schooling. Women's income seems to have a significant negative effect on the divorce probability, and men with higher incomes also lower the probability of divorce, albeit the effect is numerically small. 
As expected from the literature unemployment during the marriage raises the probability of a divorce. If the husband is unemployed, the divorce probability is 7.7 percentage points higher, whereas it is "only" 5.1 higher if the wife becomes unemployed, relatively to not being unemployed. This underlines men's position as breadwinners and also that unemployment can be very stressful. Therefore, as unemployment is greater among immigrants than among natives, it is not surprising that controlling for unemployment lowers the divorce probabilities for coethnic and inter-ethnic couples compared with native couples. For first-generation couples the divorce rate is now 3.6 percentage points lower than for native couples, and for secondgeneration couples the probability is almost similar, 3.5 percentage points. Other co-ethnic couples (mixed first- and second-generation) showed to have even lower divorce probabilities, namely 8.5 percentage points lower for first-generation men married to second-generation women and 9.4 percentage points lower for second-generation men married to firstgeneration women, relatively to native couples' divorce rates. A formal test of these differences is found in Appendix Table 2.

Inter-ethnic couples where the husband is a first-generation immigrant and the wife a native are still the most likely to divorce; the probability is 6.1 percentage points higher than for native couples. Moreover, native husbands married to second-generation immigrant wives are more likely (1.7 percentage points) to be divorced than are natives, which is also the case for couples where the husband is a second-generation immigrant and the wife is native (1.3 percentage points). For native men married to first-generation immigrant women the divorce rate is no different from that of native couples. This shows that controlling for demographic and socioeconomic characteristics lowers the divorce probability for inter-ethnic couples compared with native couples, but the change is in general moderate and most types of inter-ethnic couples still face a higher divorce risk than do native couples.

For co-ethnic couples the changes in estimates from column 1 to 3 are substantial and underline the importance of understanding the different socioeconomic characteristics when studying the divorce behavior among immigrants and natives. The co-ethnic couples have fewer economic resources and more often experience unemployment, which might be part of the explanation for their divorce behavior. Furthermore, couples with a combination of first- and second-generation immigrants seem to have particularly low divorce probabilities, given their socioeconomic status. This might indicate that second-generation immigrants who find their spouse in the country of origin are more conservative and are therefore less likely to divorce than those married to another second-generation immigrant or a native. 


\section{Conclusion}

In this study we analyze whether some types of ethnic couple divorce more frequently than others and whether their divorce patterns differ from those of natives. Inter-ethnic marriages are often associated with higher divorce rates, but the existing literature does not specify whether it is the husband or the wife who is the immigrant. We also investigate the differences in divorce patterns for combinations of first- and second-generation immigrants.

We use register data from Statistics Denmark and include all couples of Danish and nonWestern origin married (first time) within a given year in the period 1990 to 2009. Based on information about country of origin and-for immigrants-age on arrival, we distinguish between three types of spouse: persons of native Danish origin, first-generation non-Western immigrants, and second-generation non-Western immigrants. An immigrant is considered as second-generation if $\mathrm{s} / \mathrm{he}$ was born in Denmark or was younger than 15 years on arrival.

Based on these three ethnic types of spouse, we identify nine match types depending on the ethnic origin of both husband and wife: native couples, four types of inter-ethnic couple (including a native and an immigrant) and four types of co-ethnic couple (including two immigrants).

We analyze the divorce probability for these different types of couple five years after they were married. Initially, we find that all inter-ethnic and co-ethnic couples between two firstgeneration or two second-generation immigrants are more likely to divorce than native couples. First-generation men married to native women are especially likely to divorce. Controlling for demographic and socioeconomic characteristics for both husband and wife lowers the divorce probability for inter-ethnic couples compared with native couples. However, the change is moderate and most types of inter-ethnic couples still face a higher divorce risk than do native couples, first-generation men married to native women in particular.

For co-ethnic couples the changes are substantial and underline the importance of controlling for socioeconomic characteristics when studying the divorce behavior among immigrants and natives. The co-ethnic couples have fewer economic resources and are more often unemployed, which might contribute to the explanation for their divorce behavior relatively to that of natives. Hence, after the control all co-ethnic couples have a lower divorce risk than native couples do, and those with the lowest divorce probability are couples with a first- and secondgeneration immigrant.

In conclusion, the divorce rates of co-ethnic, inter-ethnic and native couples are significantly different from each other even when controlling for age differentials, different educational background and incomes, which indicates that the integration process has a long way to go if the likelihood of divorce should be randomly distributed within the population in Denmark. 


\section{References:}

Allan, D. W. 1992. 'Marriage and Divorce: Comments', American Economic Review, 82 (3), 679685.

Andersson, G. Obucina, O. and Scott, K. 2015. 'Marriage and divorce of immigrants and descendants of immigrants in Sweden'. Demographic Research. 33 (2), 31-64.

Becker, G. S. 1973. 'A Theory of Marriage Part I'. Journal of Political Economy, 81 (4), 813-846.

Becker, G. S. 1974. 'A Theory of Marriage Part II'. Journal of Political Economy, 82 (2), 11-26.

Becker, G. S. 1993. 'A Treatise on the Family, Enlarged Edition' Harvard University Press, Cambridge, MA.

Bratter, J. L. and King, R. B., 2008. But will it Last? Martial Instability among Interracial and Same-Race couples. Family Relations. 57, 160-171.

Browning, M., P-A. Chiappori and Y. Weiss. 2014. Economics of the Family. Cambridge University Press.

Casper, L. M. and Bianchi, S.M. 2002. Continuity and change in the American family. Sage Publications. Thousand Oaks, CA.

Celikaksoy, A. E., H. S. Nielsen and M. Verner, 2006. Marriage Migration: Just Another Case of Positive Assortative Matching?, Review of Economics of the Household, 4, 272-293.

Curtis, K.T. and Ellison, C.G., 2002. Religious Heterogamy and Marital Conflict. Journal of Family Issues. 23/4. 551-576.

Eechhaut, M.C.W., Lievens, J. and Van de Putte, B. 2011. Partner Selection and Divorce in Ethnic Minorities: Distinguishing Between Two Types of Ethnic Homogamous Marriages. International Migration Review. 45/2, 269-296.

Feng, Z., Boyle, P., van Ham, M. and Raab, G.M., 2012. Are Mixed-Ethnic Unions More Likely to Dissolve Than Co-Ethnic Unions? New Evidence from Britain. European Journal of Population. Doi 10.1007/s10680-012.9259-0.

Friedberg, Leora. 1998. 'Did Unilateral Divorce Raise Divorce Rates? Evidence From Panel Data', American Economic Review 88(3), 608-627.

Frimmel, Wolfgang, Martin Halla and Rudolf Winter-Ebmer. 2013. Journal of the Royal Statistical Society: Series A, 176 (4), 907-929.

Furtado, D., Marcén, M. and Sevilla-Sanz, A., 2011. Does Cultured Affect Divorce Decisions? Evidence from European Immigrants in the US. IZA DP No. 5960. [Demography. 2013. 50(3), 1013-1038] 
Jorgensen, S.R. and Klein, D.M., 1979. Sociocultural Heterogamy, Dissensus, and Conflict in Marriage. Pacific Sociological Review. 22/1, 51-75.

Kalmijn, M., de Graaf, P.M. and Janssen, J.P.G., 2005. Intermarriage and the Risk of Divorce in the Netherlands: The Effects of Differences in Religion and in Nationality, 1974-1994. Population Studies. 59/1, 71-85.

Meng, X. and Gregory, G.R. 2005 'Intermarriage and the Economic Assimilation of Immigrants'. Journal of Labor Economics, 23 (1), 135-174.

Peters, H. E. 1986. Marriage and divorce: Informational Constraints and Private Contracting, American Economic Review, 76, 437-454.

Portes, A. and Böröcz, J., 1989. Contemporary Immigration: Theoretical Perspectives on its Determinants and Modes of Incorporation. International Migration Review. 23/3, 606-630.

Ruggles, S. 1997. The rise of divorce and separation in the United States, 1880-1990. Demography 34, 455-466.

Schultz-Nielsen, M. L. \& Bonke, J. 2013. Integration blandt ikke-vestlige indvandrere. Arbejde, familie, netværk og forbrug. (Integration among non-Western immigrants. Work, family, network and consumption). English summary. Rockwool Foundation Research Unit. University of Sourthern Denmark.

Schultz-Nielsen, M. L. 2010. Chapter 3 'Marriage and Education among immigrants' in Essays in Migration and Fertility, Ph.D-dissertation 2010:1. Aarhus School of Business.

Statistics Denmark. 2010. Indvandrere I Danmark 2010 (Immigrants in Denmark 2010).

Statistics Denmark. 2013a. Indvandrere I Danmark 2013 (Immigrants in Denmark 2013).

Statistics Denmark. 2013b. Statistisk Tiårsoversigt 2013 (Statistical ten-year review 2013).

Svarer, M. and M. Verner. 2008. Do Children Stabilize Relationships in Denmark? Journal of Population Economics, 21/2, 395-417.

Tzeng, M. S., 1992. The Effects of Socioeconomic Heterogamy and Changes on Marital Dissolution for First Marriage. Journal of Marriage and the Family. 54/3. 609-619.

UNDP. 2013. Human Development Report 2013 - The Rise of the South: Human Progress in a Diverse World.

United States Census Bureau. 2011. Number, Timing, and Duration of Marriages and Divorces: 2009.

Wolfers, J. 2006. 'Did Unilateral Divorce Raise Divorce Rates? A Reconciliation and New Results', American Economic Review 96(5), 1802-1820. 
Yi, C. C. and Chien, W. Y., 2006. Does Conjugal Disparity Affect Marital Relations? Current Sociology. 54/2, 229-255. 
Appendix Table 1. Probability of being divorced after 5 years of marriage by match type, Probit model.

\begin{tabular}{|c|c|c|c|c|c|c|c|c|c|}
\hline & $\begin{array}{c}(1) \\
\text { Estimate }\end{array}$ & & St. err. & $\begin{array}{c}\text { (2) } \\
\text { Estimate }\end{array}$ & & St. err. & $\begin{array}{c}(3) \\
\text { Estimate }\end{array}$ & & St. err. \\
\hline $\begin{array}{l}\text { Native men \& native women } \\
\text { Co-ethnic couples }\end{array}$ & - & & & - & & & - & & \\
\hline 1. gen. men \& 1. gen. women & 0.0867 & $* * *$ & $(0.022)$ & -0.0598 & $* *$ & $(0.025)$ & -0.2798 & $* * *$ & $(0.038)$ \\
\hline 1. gen. men \& 2. gen. women & 0.0169 & & $(0.039)$ & -0.4224 & $* * *$ & $(0.050)$ & -0.6634 & $* * *$ & $(0.058)$ \\
\hline 2. gen. men \& 1. gen. women & -0.1380 & $* * *$ & $(0.052)$ & -0.5648 & $* * *$ & $(0.062)$ & -0.7347 & $* * *$ & $(0.070)$ \\
\hline $\begin{array}{l}\text { 2. gen. men \& } 2 \text {. gen. women } \\
\text { Inter-ethnic couples }\end{array}$ & 0.1664 & $* * *$ & (0.039) & -0.2026 & $* * *$ & $(0.046)$ & -0.2720 & $* * *$ & (0.047) \\
\hline Native men \& 1 . gen. women & 0.1344 & $* * *$ & $(0.022)$ & 0.0799 & $* * *$ & $(0.023)$ & 0.0286 & & $(0.034)$ \\
\hline Native men \& 2. gen. women & 0.2444 & $* * *$ & $(0.053)$ & 0.1289 & $* *$ & $(0.054)$ & 0.1293 & $* *$ & $(0.056)$ \\
\hline 1. gen. men \& native women & 0.7828 & $* * *$ & $(0.021)$ & 0.7215 & $* * *$ & $(0.023)$ & 0.4730 & $* * *$ & $(0.033)$ \\
\hline 2. gen. men \& native women & 0.2819 & $* * *$ & $(0.058)$ & 0.1777 & $* * *$ & $(0.059)$ & 0.1019 & $*$ & $(0.061)$ \\
\hline Women's age at marriage & & & & -0.3921 & $* * *$ & $(0.051)$ & -0.2033 & $* * *$ & (0.048) \\
\hline Women's age at marriage ${ }^{2}$ & & & & 0.0098 & $* * *$ & $(0.002)$ & 0.0052 & $* * *$ & $(0.001)$ \\
\hline Women's age at marriage ${ }^{3}$ & & & & -0.0001 & $* * *$ & $(0.000)$ & -0.0000 & $* * *$ & $(0.000)$ \\
\hline $\begin{array}{l}\text { Man less than two years } \\
\text { older than woman }(0 / 1)\end{array}$ & & & & 0.0822 & $* * *$ & $(0.021)$ & 0.0561 & $* * *$ & $(0.022)$ \\
\hline $\begin{array}{l}\text { Man more than two years } \\
\text { older than woman }(0 / 1)\end{array}$ & & & & 0.0824 & $* * *$ & $(0.025)$ & 0.0642 & $* *$ & $(0.025)$ \\
\hline $\begin{array}{l}\text { Women's educational length, } \\
\text { years }\end{array}$ & & & & & & & -0.1003 & $* * *$ & $(0.005)$ \\
\hline $\begin{array}{l}\Delta \text { educational length (men- } \\
\text { women), years }\end{array}$ & & & & & & & -0.0479 & $* * *$ & $(0.004)$ \\
\hline $\begin{array}{l}\text { Women's education missing } \\
(0 / 1)\end{array}$ & & & & & & & -0.6035 & $* * *$ & $(0.072)$ \\
\hline $\begin{array}{l}\text { Men's education missing } \\
(0 / 1)\end{array}$ & & & & & & & -0.4852 & $* * *$ & $(0.070)$ \\
\hline $\begin{array}{l}\text { Women's gross income in } \\
\text { DKK } 10,000\end{array}$ & & & & & & & -0.0019 & & $(0.001)$ \\
\hline $\begin{array}{l}\Delta \text { income (men-women) in } \\
\text { DKK } 10,000\end{array}$ & & & & & & & -0.0035 & $* * *$ & $(0.001)$ \\
\hline $\begin{array}{l}\text { Women's unemployment } \\
\text { rate }\end{array}$ & & & & & & & 0.3948 & $* * *$ & $(0.049)$ \\
\hline Men's unemployment rate & & & & & & & 0.5966 & $* * *$ & $(0.054)$ \\
\hline Constant & -1.4906 & $* * *$ & $(0.009)$ & 3.4812 & $* * *$ & $(0.552)$ & 2.3875 & $* * *$ & $(0.514)$ \\
\hline Observations & 71535 & & & 71535 & & & 71227 & & \\
\hline Pseudo $R^{2}$ & 0.007 & & & 0.022 & & & 0.054 & & \\
\hline
\end{tabular}

Robust standard errors in parentheses

${ }^{*} \mathrm{p}<.10,{ }^{* *} \mathrm{p}<.05, * * * \mathrm{p}<.01$ 
Appendix Table 2. Difference in probability of divorce, $p$-values

\begin{tabular}{lccc}
\hline \multirow{2}{*}{ Type of man } & Models, Appendix Table 1 \\
& 0.0492 & 0.3893 & 0.1091 \\
\hline Danish & 0.1030 & 0.0000 & 0.0000 \\
1. generation & 0.0000 & 0.0000 & 0.0000 \\
2. generation & (2) & (3) \\
\hline Note: For the regressions shown in Appendix Table 1 it is tested whether there is a difference in probability \\
of divorce for the same type of man married to a first- or second-generation woman. $\mathrm{H}_{0}$ : there is no differ- \\
ence.
\end{tabular}


Appendix Table 3. Robustness check: Probability of being divorced, marginal effects. From countries with more than 200 couples including a second-generation immigrant. ${ }^{1}$

\begin{tabular}{|c|c|c|c|c|c|c|c|c|c|}
\hline & $\begin{array}{c}\text { (1) } \\
\text { Marginal } \\
\text { effect }\end{array}$ & & St. err. & $\begin{array}{c}\text { (2) } \\
\text { Marginal } \\
\text { effect }\end{array}$ & & St. err. & $\begin{array}{c}\text { (3) } \\
\text { Marginal } \\
\text { effect }\end{array}$ & & St. err. \\
\hline $\begin{array}{l}\text { Native men \& native women } \\
\text { Co-ethnic couples }\end{array}$ & - & & & - & & & - & & \\
\hline 1. gen. men \& 1. gen. women & 0.0089 & $* *$ & $(0.004)$ & -0.0145 & $* * *$ & $(0.004)$ & -0.0430 & $* * *$ & $(0.006)$ \\
\hline 1. gen. men \& 2. gen. women & -0.0033 & & $(0.006)$ & -0.0641 & $* * *$ & $(0.007)$ & -0.0928 & $* * *$ & (0.008) \\
\hline 2. gen. men \& 1. gen. women & -0.0275 & $* * *$ & $(0.008)$ & -0.0889 & $* * *$ & (0.009) & -0.1098 & $* * *$ & $(0.010)$ \\
\hline $\begin{array}{l}\text { 2. gen. men \& } 2 \text {. gen. women } \\
\text { Inter-ethnic couples }\end{array}$ & 0.0224 & $* * *$ & $(0.005)$ & -0.0288 & $* * *$ & $(0.006)$ & -0.0366 & $* * *$ & $(0.006)$ \\
\hline Native men \& 1. gen. women & 0.0181 & $* * *$ & $(0.003)$ & 0.0102 & $* * *$ & $(0.003)$ & 0.0018 & & $(0.005)$ \\
\hline Native men \& 2. gen. women & 0.0328 & $* * *$ & $(0.007)$ & 0.0165 & $* *$ & $(0.007)$ & 0.0161 & $* *$ & $(0.007)$ \\
\hline 1. gen. men \& native women & 0.1052 & $* * *$ & (0.003) & 0.0953 & $* * *$ & $(0.003)$ & 0.0608 & $* * *$ & (0.004) \\
\hline 2. gen. men \& native women & 0.0379 & $* * *$ & $(0.008)$ & 0.0231 & $* * *$ & $(0.008)$ & 0.0127 & & $(0.008)$ \\
\hline Controls I & & & & & & & & & \\
\hline Women's age at marriage & & & & -0.0049 & $* * *$ & $(0.000)$ & -0.0029 & $* * *$ & $(0.000)$ \\
\hline $\begin{array}{l}\text { Man less than two years older } \\
\text { than woman }(0 / 1)\end{array}$ & & & & 0.0106 & $* * *$ & $(0.003)$ & 0.0069 & $* *$ & $(0.003)$ \\
\hline $\begin{array}{l}\text { Man more than two years } \\
\text { older than woman }(0 / 1)\end{array}$ & & & & 0.0114 & $* * *$ & $(0.003)$ & 0.0085 & $* * *$ & $(0.003)$ \\
\hline Controls II & & & & & & & & & \\
\hline $\begin{array}{l}\text { Women's educational length, } \\
\text { years }\end{array}$ & & & & & & & -0.0130 & $* * *$ & $(0.001)$ \\
\hline $\begin{array}{l}\Delta \text { educational length (men- } \\
\text { women), years }\end{array}$ & & & & & & & -0.0062 & $* * *$ & $(0.001)$ \\
\hline $\begin{array}{l}\text { Women's education missing } \\
(0 / 1)\end{array}$ & & & & & & & -0.0745 & $* * *$ & $(0.010)$ \\
\hline $\begin{array}{l}\text { Men's education missing } \\
(0 / 1)\end{array}$ & & & & & & & -0.0633 & $* * *$ & $(0.010)$ \\
\hline $\begin{array}{l}\text { Women's gross income in } \\
\text { DKK } 10,000\end{array}$ & & & & & & & -0.0002 & & $(0.000)$ \\
\hline $\begin{array}{l}\Delta \text { income (men-women) in } \\
\text { DKK } 10,000\end{array}$ & & & & & & & -0.0004 & $* * *$ & $(0.000)$ \\
\hline Women's unemployment rate & & & & & & & 0.0510 & $* * *$ & $(0.006)$ \\
\hline Men's unemployment rate & & & & & & & 0.0781 & $* * *$ & $(0.007)$ \\
\hline Observations & 67712 & & & 67712 & & & 67439 & & \\
\hline Pseudo $\mathrm{R}^{2}$ & 0.007 & & & 0.023 & & & 0.055 & & \\
\hline
\end{tabular}

Delta method standard errors in parentheses

${ }^{*} \mathrm{p}<.10,{ }^{* *} \mathrm{p}<.05,{ }^{* * *} \mathrm{p}<.01$

${ }^{1}$ These countries include: Turkey, Pakistan, Vietnam, Yugoslavia, Lebanon, Morocco, Bosnia-Hercegovina, Iran, Iraq and Macedonia. 
Appendix Table 4. Robustness check: Probability of being divorced, marginal effects. When excluding native couples, where the women is 23 years or younger at marriage.

\begin{tabular}{|c|c|c|c|c|c|c|c|c|c|}
\hline & $\begin{array}{c}\text { (1) } \\
\text { Marginal } \\
\text { effect }\end{array}$ & & St. err. & $\begin{array}{c}\text { (2) } \\
\text { Marginal } \\
\text { effect }\end{array}$ & & St. err. & $\begin{array}{c}\text { (3) } \\
\text { Marginal } \\
\text { effect }\end{array}$ & & St. err. \\
\hline $\begin{array}{l}\text { Native men \& native women } \\
\text { Co-ethnic couples }\end{array}$ & - & & & - & & & - & & \\
\hline 1. gen. men \& 1. gen. women & 0.0181 & $* * *$ & $(0.003)$ & 0.0070 & $* *$ & $(0.003)$ & -0.0223 & $* * *$ & $(0.005)$ \\
\hline 1. gen. men \& 2. gen. women & 0.0093 & * & $(0.005)$ & -0.0205 & $* * *$ & $(0.007)$ & -0.0532 & $* * *$ & $(0.008)$ \\
\hline 2. gen. men \& 1. gen. women & -0.0099 & & $(0.006)$ & -0.0389 & $* * *$ & $(0.008)$ & -0.0661 & $* * *$ & $(0.009)$ \\
\hline 2. gen. men \& 2. gen. women & 0.0280 & $* * *$ & $(0.005)$ & 0.0023 & & $(0.006)$ & -0.0120 & $*$ & $(0.006)$ \\
\hline Inter-ethnic couples & & & & & & & & & \\
\hline Native men \& 1. gen. women & 0.0240 & $* * *$ & $(0.003)$ & 0.0176 & $* * *$ & $(0.003)$ & 0.0080 & * & $(0.004)$ \\
\hline Native men \& 2. gen. women & 0.0377 & $* * *$ & $(0.007)$ & 0.0272 & $* * *$ & $(0.007)$ & 0.0242 & $* * *$ & $(0.007)$ \\
\hline 1. gen. men \& native women & 0.1048 & $* * *$ & $(0.002)$ & 0.0983 & $* * *$ & $(0.003)$ & 0.0657 & $* * *$ & $(0.004)$ \\
\hline 2. gen. men \& native women & 0.0424 & $* * *$ & $(0.007)$ & 0.0326 & $* * *$ & $(0.007)$ & 0.0207 & $* * *$ & $(0.007)$ \\
\hline Women's age at marriage & & & & -0.0020 & $* * *$ & $(0.000)$ & -0.0011 & *** & $(0.000)$ \\
\hline $\begin{array}{l}\text { Man less than two years older } \\
\text { than woman }(0 / 1)\end{array}$ & & & & 0.0109 & $* * *$ & $(0.003)$ & 0.0078 & $* * *$ & $(0.003)$ \\
\hline $\begin{array}{l}\text { Man more than two years } \\
\text { older than woman }(0 / 1)\end{array}$ & & & & 0.0100 & $* * *$ & $(0.003)$ & 0.0073 & $* *$ & $(0.003)$ \\
\hline $\begin{array}{l}\text { Women's educational length, } \\
\text { years }\end{array}$ & & & & & & & -0.0117 & $* * *$ & $(0.001)$ \\
\hline $\begin{array}{l}\Delta \text { educational length (men- } \\
\text { women), years }\end{array}$ & & & & & & & -0.0058 & $* * *$ & $(0.001)$ \\
\hline $\begin{array}{l}\text { Women's education missing } \\
(0 / 1)\end{array}$ & & & & & & & -0.0647 & $* * *$ & $(0.009)$ \\
\hline $\begin{array}{l}\text { Men's education missing } \\
(0 / 1)\end{array}$ & & & & & & & -0.0630 & $* * *$ & $(0.009)$ \\
\hline $\begin{array}{l}\text { Women's gross income in } \\
\text { DKK } 10,000\end{array}$ & & & & & & & -0.0002 & & $(0.000)$ \\
\hline $\begin{array}{l}\Delta \text { income (men-women) in } \\
\text { DKK } 10,000\end{array}$ & & & & & & & -0.0004 & $* * *$ & $(0.000)$ \\
\hline Women's unemployment rate & & & & & & & 0.0487 & $* * *$ & $(0.006)$ \\
\hline Men's unemployment rate & & & & & & & 0.0662 & $* * *$ & $(0.007)$ \\
\hline Observations & 67829 & & & 67829 & & & 67521 & & \\
\hline Pseudo $\mathrm{R}^{2}$ & 0.010 & & & 0.013 & & & 0.045 & & \\
\hline
\end{tabular}

Delta method Standard errors in parentheses

${ }^{*} \mathrm{p}<.10,{ }^{* *} \mathrm{p}<.05, * * * \mathrm{p}<.01$ 